\title{
Riots on the News in West Borneo
}

Pontianak: STAIN Pontianak Press, 2008

\section{By Zaenuddin H. Prasojo}

Reviewed by

Dian Kartika Sari

(Pontianak State Institute of Islamic Studies)

West Borneo had a long story of visible social conflict among ethnics dwelling within different parts of regencies in the West Borneo many years ago. The conflict itself was not merely about the distinction of ethnicity, however, the powerful factors contributed to the event namely social and economic. Furthermore, the conflict which turned to violence became a global issue since mass media kept an eye on the news intensely. The news, moreover, could shower peace among the audience, on the other hand could aggravate the riot. Thus, the issue of conflict studies or conflict resolution has caught the attention of many scholars to learn more about conflict from all over the world. One of the scholars who also concerns on the conflict and originally comes from West Borneo, Zaenuddin has written a book about conflict studies, "Riots on the News in West Borneo". This book, actually, is the development of his thesis, hence, it would be highly recommended for those who concerns on anthropology, social, and cultural issues to consume this book.

As far as I am concerned, this is an outstanding book because it is fully written in English which means the advanced development of Indonesian scholars. Besides, it has deep information about riots as well. This book consists of five chapters which elaborates particular issues about conflict. Chapter one is Introduction, which tells the reader about West Borneo in 1990s on the eyes of media and conflict studies. Then, the first chapter is divided into three parts which displays an understanding between mass media and the relationships of ethnic groups in West Borneo. In addition, Zaenuddin also mentions the experts' thoughts about ethnicities and their relations with media and conflict studies. Therefore, in the introduction, the writer tells us about conflicts that happen in West Borneo such as ethnic conflicts among the Madurese, Malay, Dayak, Chinese, and Others. These happened in some places like Pontianak, Sanggau Ledo, Sambas, Bengkayang, and so forth.

First of all, the book states that the conflicts were caused by economic and cultural problems, especially for those directly involved in the community. Moreover, this book explains about how the media take a look the conflict especially in West Borneo. Because this book addresses the questions of how 
the riots happened and how people perceived those violation by analyzing how their issues were presented by the media. Using media as a resource for the analysis is once found in the news about the conflict, this work will contribute to the academic resources of media research especially in West Borneo. The focus of this project is to reveal how the conflict between the Dayak and the Madurese in West Borneo during 1997 was constructed by the media especially by the Akcaya Pontianak Post and Kompas. The reason why Zaenuddin decided to carry out the research through both printed media is their news of the riots has been presented comprehensively and continuously. Besides, in chapter one, a writer talks about Ethnic Relationship in West Borneo based on the media. The mass media brainwashes human mind in many aspects, wherever they are. By conducting this research, people will get information about the conflict not only from field of studies but also from media studies. Furthermore, Zaenuddin used discourse analysis to analyze texts in the media especially in newspapers while conducting his research in the conflict studies.

In chapter two, the writer brings the reader to know comprehendly about West Borneo especially its people and culture. Moreover, the reader will be introduced generally what West Borneo looks like, geographical view, for instance. The writer explains about West Borneo that is a well-known province which has "thousands of rivers" because its have thousands of both big and small rivers. Further ahead, Sungai Kapuas is famous as the longest river in Indonesia. Besides, he also talks about the equator line laid through Pontianak City which means that West Borneo is a tropical area which is damp and has high temperature. Therefore, the writer also discusses the agriculture products produced in West Borneo, economic structure, living societies, social life and what kind activities they usually perform daily, and at the end of the chapter Zaenuddin explains the variety of ethnic and religious relations in West Borneo.

Zaenuddin writes about Dayak and Madurese Once in West Borneo in the third chapter. He begins with the history of a broken relationship between the Dayak and the Madurese. The Dayak and The Madurese had been dealing with conflict since 1950's and lasted around 1999. Furthermore, Zaenuddin cited Ibrahim's thesis about the classifications of ethnic conflicts in West Borneo which stated three categpries of ethnic conflicts: close and open conflicts, individual and group conflict, and, vertical and horizontal conflict. Besides, the writer tries to recapitulate the researchers' investigation on the factors affecting this conflict such as cultural issues, economic gaps, educational problem, and political and social access problems. In the end of this chapter 
the reader will find the reason why many conflicts broke out in West Borneo and how the conflicts happening between the Dayak and the Madurese affects people's life, which are elaborated greatly by the writer.

In chapter four, the writer presents the mass media which is used as medium of the research. It entitles When the mass media talks: Pontianak Post and Kompas on the riots emerging in West Borneo in 1997. Further ahead, the news is elaborated fairly between two newspapers; Pontianak Post and Kompas, thus, the reader awares of the thorough information about conflicts in West Borneo. At the first chapter, the reader has been told why the writer choose these two newspapers, the reason is about comprehensively and continuously the news of conflicts written on these published media. Besides, he talks about the risk if the news about conflict has shown up in a society due to public knowledge and perceptions of the riots as reflected in the news.

In the last chapter, Zaenuddin wraps up the whole writing by concluding and making a reflection in order to create social awareness about living in harmony in West Borneo. This book becomes very important not only for people involved in the riots to learn what is reported in the mass media, but also for many people in West Borneo to take a lesson from those conflicts. Moreover, the distinction among ethnics is unavoidable and should be faced in an open-mindedness through free dialogues or other preventive action. 